\title{
Amongst the unbelievable: Rage, faith and reason in selected writings by V.S. Naipaul
}

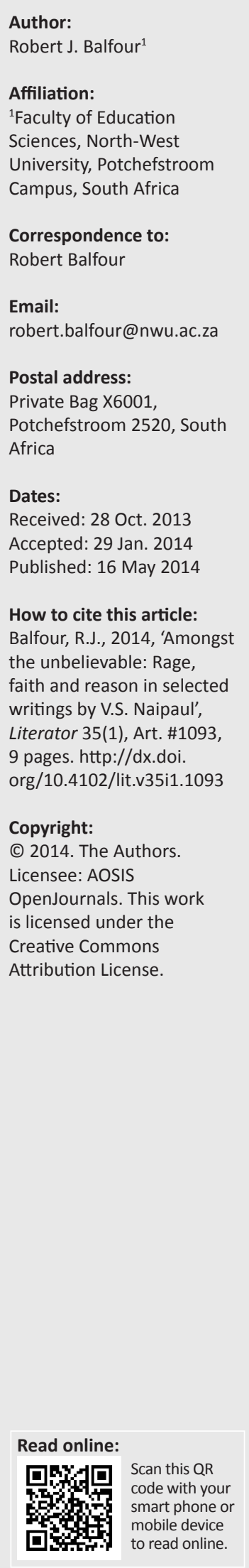

This article focuses on the representation of faith as conveyed by Naipaul in the course of four travelogues. Drawing on historical scholarship pertaining to Islamic societies in transition, and comparing this to a selection of the literary critical reception that Naipaul's writing about Islam has evoked, I argue for a revision of literary readings of Naipaul's travelogues. My premise is that the author's subject positioning influences both a self-critical as well as more compassionate perspective on the relationship between faith and political transition in developing societies.

Te midde van die ongelooflike: Woede, geloof en rede in uitgesoeke werke deur V.S. Naipaul. Hierdie artikel fokus op die uitbeelding van geloof in die loop van vier reisbeskrywings deur Naipaul. Met die gebruik van geskiedkundige navorsing oor Islamitiese samelewings tydens verandering, en 'n vergelyking hiervan met 'n keur van die literêrkritiese ontvangs wat Naipaul se skryfwerk oor Islam ontlok het, bepleit ek 'n hersiening van die literêre leeswerk van Naipaul se reisbeskrywings. My uitgangspunt is dat die outeur se posisionering van die onderwerp beide 'n selfkritiese én 'n deernisvoller perspektief oor die verhouding tussen geloof en politieke oorgang in ontwikkelende samelewings beïnvloed.

\section{Introduction}

Representations of faith (the Islamic faith in particular) as problematised by V.S. Naipaul are analysed in this article. Naipaul shows that whilst Islam offers some intellectual and cultural possibilities, these possibilities are contorted by the differences imposed by faith on converted people, the faithless and the spaces occupied by both in a globalised world. I argue that the author's subject positioning steers the reader into a particular reading of faith. With reference to political and sociological analyses of Islam, I will show why Naipaul's perspectives on Islam are revealing in terms of the impact of Islam on third world (postcolonial) states in transition. I argue that the perspectives offered by Naipaul also reveal his anxieties and ambivalences with regards to the impact of colonialism more generally. I believe a re-reading of the travel texts written by Naipaul, and the literary critical reception of these, is justified, in relation to selected analyses of Islam as offered by sociologists and historians. At the turn of the new century religious strife, together with Western interference, often seem to have led to an escalation in violence. That escalation points to the need to re-examine perspectives adopted as authoritative in order to ascertain whether the critique of Naipaul is merited.

The article is structured in terms of an introduction and five sections to explore the above argument. The first section specifically examines the complexity of Naipaul's subject positioning with reference to four travel texts: An area of darkness (1964), Among the believers (1981), India: A million mutinies now (1990), and Beyond belief (1998). The possibilities offered by Naipaul to the reader are framed and filtered at number of levels, even though the ostensible focus appears to be Islam. In this section I show that the delimitation of subject position and the selection of interviewees make for a highly selective reading of Islam. Section two, 'Transitions to faith', concerns itself with perspectives offered by the narrator and his interviewees on the effects of conversion to Islam, whilst the third section explores faith and its relationship to the state. Naipaul suggests that intellectual tolerance of difference is associated with modernity and so the fourth section provides a discussion of faith in relation to intellectual work. In this section I also suggest that the filtering process described in the first section, makes for a series of insights revealing the author's perspectives on faith and tolerance. The fifth section explores the associations between faith and daily life.

The methodology here is twofold: Firstly, a description of Naipaul's interrogation of the legacy of Orientalism and colonialism in relation to Islam with some reference to the literary critical 
reception of Naipaul's already well documented works. Secondly, by drawing on historical texts concerning Islam, I demonstrate that the discourse and ideas evident in political analyses do not differ substantively from the analyses offered by Naipaul in the travelogues. Naipaul, despite shifting between apparent neutrality and cutting criticism, is deeply compassionate about the dilemmas and choices offered to the convert, which he views at best as ambiguous, and at worst as a corrupted distortion of the past, of identity, and of future possibilities.

In order to support this argument I consider the work of certain literary and social commentators in the context of decolonisation, from Nixon (1992), Said (1994), Bhabha (1994), and Feder's (2001) perspectives on Naipaul on Islam, to Waines (2003), Ahmed (2004), Zakariyya (2005), and Mazrui's (2006) descriptions of Islamic states in transition. Whilst the first four are literary critics, the latter four scholars are historians or political scientists, and, with the exception of Waines, are Muslim themselves. Re-reading Naipaul from the perspectives of such scholars enables me to consider afresh the literary reception of the Islamic travels.

\section{Naipaul and authorial subjectivity}

I begin my argument by suggesting that Naipaul's representation of Islam is revealing of his own subjectivities and, indeed, anxieties. Naipaul has been described as 'one of the greatest living writers in the English language' (Donadio 2005:1). Every book is prefaced with a statement concerning the major prizes accorded to his work, including, most recently in 2001, the Nobel Prize. He has been described in the Times Literary Supplement (Boyd 2010:1) and The New York Review of Books (Rush 2010:4) as an influential opinion maker with regards to the postcolonial world; a prophet no less of Third World affairs (Donadio 2005:1). It is well-known that his views of the postcolonial era are not positive: Naipaul (1979:31) has on occasion described postcolonial states as half-made, and as being in the process of unmaking. Because of the acerbity of his comments, he has also been criticised for being neurotic, contemptuous, and even racist (see Anjum 2001:1; Gibbons 2001:1). In short, he remains a controversial figure as well as a celebrated one, and, in the aftermath of $9 / 11$, his writing on the relationship between Islam and its converted peoples is again receiving a great deal of attention in the field of postcolonial literary scholarship. Re-reading Naipaul's Islamic travels, from the perspective of his subjectpositioning, suggests that the literary critical perspectives offered, may have neglected this dimension.

Naipaul reveals something of his role as narrator in relation to the subject of the text. In Beyond belief, a collection of travel stories undertaken whilst visiting non-Arab Muslim countries in 1995, Naipaul (1998:1) argues that 'This book is about people. It is not a book of opinion'. According to Naipaul (ibid:1), 'Islam ... makes imperial demands', requiring converts to forget or reject the past; a problematic demand in the context of a present which arises from past diasporas and conflicts which similarly demand recognition in their consequences for people. He claims that in these books, he is in the background; he is:

a discoverer of people; a finder-out of stories ... the most important thing about travel, for the writer, was the people he found himself among ... the writer retreats; and I become ... a manager of narrative. (Naipaul 1998:2)

Of the kind of person he is, even if he too becomes the character of the author-narrator in the travel narratives, very little is suggested. In Among the believers (1981) he recounts a visit to the Diamond Market in Lahore (a prostitution area):

In the old days I would have grown dizzy with excitement here. Up to my mid-thirties I had been attracted to prostitutes ... My memories of those times were not really of pleasure, however; they were more of enervation. (Naipul 1981:283)

Candour such as this, which reveals degrees of distress and enervation that translate into anxiety, is rare in Naipaul's travel books, and is illuminating for reasons elaborated upon later.

Who is V.S. Naipaul? What is he? And, what psychic baggage accompanies the Islamic journeys? These questions are useful for two reasons. Firstly, the occlusion of his subjectposition as author who dictates the script, evokes and edits it, is skilled and subtle. With the exception of the fiction, the travel narratives contain extended interviews with subjects. It is interesting to note that Naipaul seldom provides the reader with his questions, nor does he provide any of the promptings necessary to elicit the interviews described. The writer becomes the interlocutor whose questions are never articulated, but whose nature is evident in the narrative of the interviewee. Feder (2001:139) suggests aptly that Naipaul brings a strong set of beliefs to the interviews and risks becoming 'less of an inquirer of himself as well as of his informants', but I would argue that the selection of interviewees and the evident direction the narrative and interview material takes, suggests a powerful control over the narrative despite the anxiety of his own position as stranger; a point to which I return in later sections.

A second observation concerns the 'subjectivity' offered to the reader. With few exceptions Naipaul offers a Western gaze in which the attachment to religious belief is paired with an aversion of modernity, and an oppression of intellectual endeavour or the freedom to question belief, as has already been suggested by Nixon (1992), who noted that Naipaul trades on the common identification of author and reader with a Western persona. And yet he is also a 'colonial': the identity of race is one which allows him access to eminent Islamic figures for whom race, because of the association of whiteness with Western imperialism, is a barrier to communication. Naipaul, on another level, is also a sub-altern (Spivak 1988:271). The position of the sub-altern is complicated and presents few and delimited possibilities. The first of these is the possibility of resistance, whereby the sub-altern rejects the inferior identity imposed on him by the colonial world. The rejection can be total and in its totality can lead to new forms of oppression and self- 
denigration. By alerting the reader to the inconsistencies and compromises interviewees accept, one becomes aware as literary critic that this focus has implications for the author of the text, by reflecting on choices and their implications concerning his credibility and identity. Alternatively, there is the possibility of the stereotype defined by Said (1991:58) or the mimic articulated by Bhabha (1994:85). For Bhabha, whilst the mimic entails an almost wholesale adoption of the values, identity markers, and performance of a colonised subjectivity, it may become an expression either of resistance (in which case the mimicry is subversive and destabilising of colonial assumptions and terms of engagement) or assimilation, which can never be total and which appears to lead to nervous anxieties (see Bhabha 1994:85).

The observations above suggest that Naipaul presents himself either as insider or outsider depending on the context in relation to the objectives of the text. For example, in order to access his subjects he must appear to be an insider to some extent. In post-revolutionary Iran, a white and Western journalist would be unlikely to gain access to religious authorities let alone dissidents; thus it is sufficient to assume that Naipaul trades on his appearance to gain insider access. There are evidently risks associated with this, and the reader becomes aware of the tenuousness of the interaction between interviewer and interviewee, and of frequent misunderstandings; another source of anxiety.

It is clear to the reader that Naipaul is also an outsider in these encounters and in that context the preoccupation with Islam becomes interesting from a number of perspectives. For example, through the presentation of ironic insights that make use of the contrivances of pillory, satire, and joke knowledge (Coovadia 2009:4), Naipaul presents to the reader an argument about Islam with three major premises. Firstly, that the spread of Islam is the equivalent to the historical spread of (Western) colonialism. Secondly, that Islam demonises and obliterates the historical, legal, and religious past of a people, and persuades and coerces them to accept in its place an Islamic and Arabic past. Thirdly, as argued by Feder (2001:137), the journeys through nations in which Islamic revolutions have occurred, seem to reveal that where religion and the state fuse, there exist few possibilities of alternatives. Furthermore, conversion to Islam and the distortions and simplifications imposed by it, enable people (the converts) to construct ideas about observance that participate in a fantasy life which seems to imprison the intellect. Religion, then, changes attitudes to behaviour, sex, commerce, law and observance. The issue to highlight is whether the distortions as depicted are enabled by faith, or arise from the author's subjectivity and tension.

Another aspect of Naipaul's positioning is revealed in the relationship of the author to authority. Consider, for example, that all the works produced by Naipaul are prefaced by the same list of literary prizes bestowed (the knighthood and Nobel Prize) in the English speaking literary establishment. It would not seem unfair to suggest that the foregrounding of this list serves two additional purposes in relation to the establishment and maintenance of the subjectivity both offered to, and concealed from, the reader. Theroux (1998:366) suggests that, in the list, is an appeal to authority (the cultural, social and institutional forms of authority in the West). On the other hand, Naipaul claims on the grounds of gender and race authority to speak for, and write about, the East (or the decolonised world in general). At the same time, the concealment of race, gender, and cultural milieu (Naipaul's Brahmin heritage) serves a second and third purpose.

Race has already been mentioned, but gender requires further exploration. In his interviews, the removal of what Naipaul terms his 'opinion' combines with a deliberate selection of subjects to be interviewed (mostly male, almost always selected as a consequence of their exemplar status), and always through the mediation of someone young a younger; male, most often a student (for example, Aziz 1964:102 in An area of darkness, and Furqan 1998:73 in Beyond belief). There is only one interview with a woman in the texts - and the texts themselves present, for observation only, all the other women in purdah (Naipaul 1998). The interview with the one woman occurs because she is emancipated (in fact a divorcee); therefore, the positioning of the reader occurs in relation to the positioning of the interviewed subject; both are managed through an equally complicated and nuanced sensibility. That said, there is an implicit use of race and gender. The interviews themselves are often translated by an intermediary (Mehrad performs the role as intermediary for Naipaul 1998:215 in Qum) used by Naipaul to not only identify subjects to be interviewed, but also to enable access to subjects whom he seeks to interview (for example, Ayatollah Khalkhalli in Qum [Iran]) (see Naipaul 1998:217). Thus the subjectivity offered by Naipaul to his interlocutors, is not the same as that offered to the reader; both subjectivities are tacit and the dissonance between them problematic.

Thirdly, access to the author-narrator is also concealed, and when Naipaul is questioned about what he is, or what it is that he seeks, the responses are often muted, misdirected or deflected in order to enable access to the narrative Naipaul seeks in his travel writings. Thus the deference to authority (that Western enabled, male and educated authority and 'establishment'), allows for access to the audience of his adopted context, whilst the appeal made to interviewees occurs on the basis of assumed affinities. As the author straddles inside and/or outside, so too does the period in which these writings have been located, span the end of decolonisation and the emergence of globalisation.

Naipaul must have been aware at the time he wrote the Islamic travel books of earlier less prejudicial associations with the East; what Said (1991:2) refers to as 'the idea of Orient' associated with the 'romance, exotic beings, haunting memories and landscapes, [and] remarkable experiences', since he refers to the antiquity and mystique of selected Iranian cities like Qum (Naipul 1998:221). Nevertheless, the 
complex straddling suggests also that for Naipaul, these precolonial associations with the East, have as Said (1991:2) has noted, fast disappeared in the popular 20th century Western imagination. No doubt this occurred because of the perceived threat posed by Islamic states, control of oil reserves, and the resistance (sometimes in the form of terrorism, nuclear threat, the popular press) against the alleged exploitation of the Islamic states by the West as noted by cultural and literary critics writing in the 1990s (GoGwilt 1995:68). Said (1991:320) states that the Western notion of the Third World in the East (whether Middle, Near or Far) forms a more discursive terrain not only because the 'triumph of nationalism' has occurred there only in half-measure, but because it has been overshadowed by responses to the impact of Islam, what Said (1991:320) refers to as the 'attack ... on the Third world for its religious fanaticism'. In short, it can be argued that for Naipaul (1998:3), conversion, and his particular interest in the transition from the old faiths to the new, is also a means for interpreting his own experience of the anxiety of transitions from colonisation, decolonisation and neo-colonisation: ' $[i t]$ is still going on ... the extra drama [in the] background, like a cultural big bang, the steady grinding down of the old world'. I return to this idea in the concluding sections of the article. The next section explores further those transitions between outsider and/or insider to insider and/or outsider perspectives on Islam and its relationship with modernity in order to argue that the representation of modernity offered by political or sociological scholars of Islam, such as Ahmed (2004), echoes that offered by Naipaul. This suggests that the negative criticism by literary scholars of Naipaul's representation of Islam is, if not misplaced, then based on a decontextualised and a historical reading of Islamic societies in transition.

\section{Transitions to faith}

Since this article is concerned with faith, it is useful to very briefly begin with Naipaul's sense of his faith; its purpose and characteristics. Moreover, in Among the believers, Naipul (1981) states 'In Trinidad, with its many races, my Hinduism was really an attachment to my family, an attachment to my own difference'. Critically then, faith, like culture and its markers, is a means of location and of relating to the land and its communities, but in his instance, faith is an almost absent stain, a barely discernible watermark and its showing is as much evidence of a Trinidadian history, as it is the abandonment of this for the possibilities offered by Western metropolitan culture. However, there is another side to the representation of faith: faith which is living and which motivates action. Naipaul (1990) presents such faith in a later travel book as something which appears to defy reason:

It had been hard for me, emerging from the soft lake world of ... waterways and lotus, to believe what I had so suddenly come upon: bloodied bodies, blood soaked clothes, chains, whips tipped with knives and razor blades, the exalted, the deficient faces of the celebrants, and their almost arrogant demeanour ... I hadn't understood the religious-historical charge of the occasion, the underlying grief it sought to express. (p. 507)
Naipaul (1990) perceives India as a place of faiths in conflict:

... the liberation of spirit that has come to India could not come as release alone. In India, with its layer below layer of distress and cruelty, it had come as disturbance. It had come as rage and revolt. India was now a country of a million little mutinies ... supported by twenty kinds of group excess, sectarian excess, religious excess, regional excess ... people were always ready in India to let religion carry the burden of their pain.(pp. 517-518)

In 1990 already the idea that faith, or the absence of faith, can motivate rage is evident in the literary and political scholarship of the time. And, not unsurprisingly, in the relationship between faith and the faithful (especially the converted peoples in the travel texts), there is also this transmission of rage; rage rather than passion which is how the political commentator Ahmed (2004:95) describes the resurgence of Muslim protest in the 1990s. For Naipaul (1998), there is a similar perspective, though its range is extended to cover both the past and the present:

A convert's world view alters. His holy places are in Arab lands; his sacred language is Arabic. His idea of history alters. He rejects his own; he becomes ... a part of Arab history. The disturbance for societies is immense, and even after a thousand years can remain unresolved; the turning away has to be done again and again. People develop fantasies about who and what they are; and in the Islam of converted countries there is an element of neurosis and nihilism. These countries can easily be set to boil (p. 1)

The attitude displayed by Naipaul to Muslims and their reactions to the West is not without compassion, but also verges on disdain as shown in this extract from Among the believers. Faith was a:
... turning away from the life of intellect and endeavour [Feri and the doctor] have come together in a death pact. In the emotions of their Shia religion, so particular to them, they will rediscover their self-esteem ... They will no longer have to be last ... Other people in spiritually barren lands [the West particularly] will continue to produce the equipment. That expectation - of others continuing to create, of the alien, necessary civilisation going on - is implicit in the act of renunciation, and is its great flaw. (Naipaul 1981:19)

The location of the West as a presence, but unknown, and intellectually inaccessible is rendered for the reader in the binary associated with the labour and technology to produce innovation, and the relative lack of technological sophistication required to use it.

Some 18 years after Among the believers, Naipaul (1981) returns to the theme of conversion and its implications in Beyond belief and problematises the relationship between the convert, faith, gender, and race. In a passage in which he describes an Indonesian convert's efforts to convert an American man (who himself is about to wed an Indonesian woman) the following quotation is illuminating, since faith is shown to have limits when set against other essentialising elements of identity, for example, race or gender. To the convert Imaduddin says: 
'It's amazing how you've changed. You don't look like an American. You already look like an Indonesian'. The Oklahoman, straightening a sock over a foot, and looking down, said in a voice that didn't carry far, 'Still white'. (Naipaul 1998:49)

If faith is shown to have an intensely private and radicalising dimension in terms of behaviour and thought for the convert, it is equally meaningful for political movements of the period to be able to harness its passions (or rages), as described in the paragraphs to follow, in which the relationship between faith and the state in transition from a colonial dispensation to modern nation state is explored. This is important because literary scholars have focused on Naipaul's view of modern postcolonial states as half-baked and/or inadequate, but failed to note that colonialism and Western intervention are the primary causes of endemic instability.

\section{Faith and the state}

Ahmed (2004:33) suggests that after years of despotic rule, corruption and nepotism, supported in many instances by Western imperial or multi-national capitalist companies, modernity had come to be identified by Muslim thinkers as un-Islamic. 'Muslims ... asked if God had abandoned them. Other Muslims turned the question round: had they abandoned God? The answer pointed in the direction of Islam ...' and therein lay Islamic resurgence and a rejection of the West. Ahmed further argues that 'Postmodernism, with its emphasis on globalization, equality and tolerance' (ibid:191) presents a dilemma to Islam precisely because it demands the acknowledgement that Muslims live in an interconnected world in which diversity is both accepted and rejected. Such dilemmas lie on the surface in the interviews conducted by Naipaul (the Oklahoman referred to earlier, for example).

Revolution in Islamic states has come to be associated with economic, social, and religious reform. Mazrui (2006:22) notes that, economically, there has been a need to break the monopoly held by Western (colonial) power and multinational corporations on the wealth of Islamic nation states. In Beyond belief, Naipaul (1998) interviews an Iranian who lived through the 1979 Revolution:

Mehrad remembered that at the beginning of the revolution the cry was the communist one of 'Nun, Kar, Azadi', (Bread, Work, Freedom). Within a year it had changed to 'Bread, Work, and an Islamic Republic'. (p. 147)

But, having described the quick transition from a concern with social issues, to a concern with religious observance, Naipaul (1998) suggests that the role of faith as a political movement, or as ascendant over the secular state, is damaging and corrupt:

We went to the blood fountain. It used to be famous ... and it was intended to stimulate ideas of blood and sacrifice and redemption. The fountain didn't play now ... There had been too much blood. (p. 152)

Even Muslim historians of Islamic states such as Zakariyya (2005), acknowledge that far from being concerned with social issues plaguing such countries, the new religious movements:

... focused on superficial issues ... the beard, the veil ... issues of sexuality and sexual purity ... [T] he mass appeal of the Islamist movements ... is a clear expression of the totality of defeat [after 1967 by Israel]. (p. 125)

Of critical significance though, faith became a vehicle for defiance in the absence of other viable political alternatives not associated with the West.

In terms not dissimilar to Zakariyya's (2005), Naipaul (1981) depicts the association between faith and the state in Among the believers as follows:

... after the centuries of despotism, they really believed [in Pakistan] ... that the state was something apart, something that looked after itself and was ever restored. And even while with their faith they were pulling it all down — hotel, city, state they were waiting for it to start up again, to be as it was before. (p. 37)

Such ideas have also been expressed by postcolonial and other commentators. For example, Hardt and Negri (2001:132-134) suggest that whilst the nation appeared in the early 20th century to be the necessary vehicle for political modernisation, it has become 'the poisoned gift of national liberation'. Participation in a global order has created internal tensions for new nation states, as Mamdani (1996:26) points out in his analysis of the despotic power of postcolonial African states, suggesting that previous forms of despotism made for difficult conditions in the transition to democracy.

Waines (2003:215) (an American and non-Muslim historian of Islamic theocratic societies) characterises Muslim society as one in which Islamic revolutions focuses on a return to the faith, and an ever-deeper understanding of its centrality in daily life. In contrast, in the West, innovation is associated not with the mastery of religious learning, but rather of technological and societal organisation, often accompanied by spiritual loss. The fundamentalists believe that renewal would be forthcoming from the Shari'ah. As I argued earlier in relation to the less prejudicial Western associations with the East, Waines (ibid:216) also points out that until the 1870s Muslim attitudes towards the West were generally positive and characterised by curiosity rather than hostility, and that borrowing technologically from the West was permissible within the religio-spiritual superiority of Islam. Waines (ibid:238) suggests that the withdrawal of imperial power from the Middle East in the 19th century and the rise of the Zionist movement sowed the seeds of discontent with the West and furthermore, Western technological advantage came to be associated with a new crusading project, a belief not dispelled by missionary activities in the colonies. This contextualisation explains the desire to establish a religious purity in the aftermath of Western colonisation, a phenomenon problematised by Naipaul (1998):

Mr Jaffrey had had a dream of the jame towidi, the society of believers. This was a dream of re-creating things as they had 
been in the earliest days of Islam ... and the spiritual and the secular were one. It was like a dream of an ancient city state, and in the modern world it was a dangerous fantasy ... [It was] in this awareness of his own piety, which was like pride, his constant rejection of the impure, that the tyranny of the religious state began ... (pp.154-155)

In Beyond belief Naipaul (1998:245) notes that control in Iran had become ever more stringent and led to social absurdities: 'The revolution had bred strange children', he writes with reference to a new generation of Iranians, sexually defiant and more strangely radical. Naipaul, whilst in Iran, learns that the young Iranian Nazis tormented the Jews of Tehran. In Pakistan:

The state withered. But faith didn't ... the state failed ... because men had failed the faith. A purer and purer faith began to be called for. Extraordinary claims began to be made for Pakistan: it was founded as the land of the pure; it was to be the first truly Islamic state ... (Naipaul 1981:87)

Of Iran, Naipaul (1998) notes that Ayatollah Khalkhalli said: 'The mullahs are going to rule now. We are going to have ten thousand years of the Islamic Republic'.

The society of believers is characterised by submission to obedience, extortion of property or wealth by petty criminals legitimised by the theocratic state because of their faith; policing of demeanour, dress, aspect: in effect reducing the dignity of the person to a function of the state, to be defined, and changed at will. As much is described in relation to Pakistan, which Naipaul (1998) suggests:

... could be contemplated in the same way ... economically stagnant, despotically ruled ... [its] people close to hysteria ... cherished as a pioneer of the Islamic revival. Politics is combined with religion in Islam. (p. 82)

\section{The state becomes self-devouring:}

... certain fantasies had taken hold ... the Powers had decided to foist Khomeini on the Iranian people ... The establishing of an Islamic state ... was an anti-Islamic plot by the Powers, to teach Muslims a lesson. (Naipaul 1998:241)

For the author-narrator, the fusion of faith with the state offers few possibilities for even mild expressions of difference, let alone dissent:

... such a state could always be manipulated, easy to undermine, full of simple roguery. The mullahs would always hold the ring, would limit inquiry. All history of the ancient land would cease to matter ... the history of Pakistan would become only an aspect of the history of Islam ... It is a dreadful mangling of history ... too much has to be ignored or angled; there is too much fantasy. (Naipaul 1998:329)

One has to question why it is that political or social alternatives seem rare. Zakariyya (2005:16) speaks of secularism as having a special meaning in Islam: for Muslims active in society in the 1970s, secularism meant the pursuit of technology and progress, rather than the separation of church and state as it had meant for centuries in the West.
Thus 'Arab secularists advocated technological and scientific progress while resolving to eject European colonialism' (Zakariyya 2005:16). After independence, the oil and mineral wealth of the East became evident, and Zakariyya suggests that in this time the nationalists and leftists vied for power, but were eclipsed by what he terms the 'Islamists' who were focused on the establishment of the theocratic state (for example, Iran and Sudan, who introduced the Shari'ah), with its regulation of the curriculum, suppression of women's rights, policing of dress, behaviour, and sexuality, and its state nationalisation of institutions of finance, the economy and learning. According to Naipaul (1981:102), 'faith could not acknowledge secular associations or divisions'. Thus the vacuum created by decolonisation also created the conditions necessary for religious and political absolutism. What is evident in the anxieties expressed by his interviewees, is Naipaul's own anxiety about the fate of postcolonial peoples caught up in or not conforming to the new regimes, the origins of which, whilst apparently internal to the 'religion', find their sources beyond the nascent postcolonial state. Though the scholarship describes social and political developments in ways which echo the interviewee's accounts, what remains noticeable in Naipaul's work is the absence of any deviation from a narrative of Islamic-pessimism - a matter for which he has been severely critiqued (Al-Quaderi \& Habibullah 2012:23). The section to follow explores this perspective further in relation to those instances where faith does offer some possibilities other than dissolution or corruption; I argue against the general literary critical reception of Naipaul, and suggest that the anxiety attendant on the postcolonial condition is experienced both by author and interviewee.

\section{Faith and intellectual work}

Is faith the antithesis of intellectual enquiry? The authornarrator visits two newspapers shortly after the Iranian Revolution; both are anxious places: 'Remember that director. Remember that busy office ... Six months later when I went back to Tehran, that office was desolate' (Naipaul 1981:34). The destruction of the press in Iran is well-documented as is the heightening of censorship in every form (already a feature of the Shah's government) (see Mazrui 2006:24). Universities, schools, curricula, and even student political activity all came to be regulated. In his travels Naipaul sought to ascertain where centres of learning continued to thrive.

Qum, the city renowned for learning in post-revolutionary Iran, offers an opportunity to recall the scholarly affinities between the East and the West, acknowledging that eminent Muslim scholars and philosophers once influenced every aspect of learning in the West. For example:

On the pavement outside the Turkish Embassy turbaned medicine men sat with their display of powders and roots ... I had seen other[s] in Tehran and had thought of them as Iranian equivalents of the homeopathic medicine men of India. But the names these Iranians were invoking as medical authorities - as Beshad told me, after listening to their sales talk to a peasant group - were Avicenna, Galen, and Hippocrat. Avicenna ... it 
had never occurred to me that he was a Persian ... $[A]$ thousand years before ... Muslim civilisation was the central civilisation of the West. (Naipaul 1981:12)

Of the learning produced in the aftermath of decolonisation and the birth of the radical Islamic state the narrator finds evidence in a contemporary publication:

One of the English-language magazines I bought was published from the holy city of Qum. It was The Message of Peace, and, as its title warned, it was full of rage. (Naipaul 1981:34)

Absolute faith and devotion became both a vehicle for political rage against Western exploitation, as well as for spiritual desire for a new beginning and new identity.

With regards to learning and the marginalised groups (for example, women), Naipaul (1981:194) records when visiting oil-rich Indonesia, that Paydar's mother said: 'You will never gain anything from following these religious people. We have known them. These are the people who didn't let me learn reading and writing'.

For women and other marginalised groups, the new Islamic state seems to offer little. The only people who appear to have benefitted in the Islamic Republic are the clerics and men in general.

Intellectual work, where it can be found, is shown to be narrow and redundant. For example, Naipaul (1981:221) refers to the 'antique learning' of Avicenna and Farrabi, which remains key to the philosophy curriculum in Qum. Later, on a visit to a theological school, he finds a historian who is writing a History of World Philosophy, convinced of the ubiquity of Zionism (ibid:233). This description recalls Said's (1991:270, 275) observation concerning scholarship developed in a vacuum where it cannot 'critically ... examine the assumptions and principles on which ... [intellectual] work depended'.

If intellectual work arising in the context of the new Islamic state is thwarted because of faith, then the likelihood of faith being a binding, progressive and unifying force for Muslims is diminished. What Naipaul describes is the ossification of a curriculum increasingly at odds not only with secular Islamic impulses, but also the non-Islamic world. For example, in Beyond belief, Naipaul (1998) says of Imaduddin's ability to reconcile Western technological advances with Islam:

Always out there, the United States, an unacknowledged part of the world picture of every kind of modern revolutionary: the country of law and rest, and which at the end of the day a man who proclaimed himself to be on the other side - in politics, culture, or religion - could make peace and on whose goodwill he could throw himself. (p. 17)

Whilst Naipaul is aware of the influence of political change on the lives of those whom he interviews, the perspectives offered are tragic rather than inflammatory, pathetic rather than preoccupied with rage.

\section{Faith and living}

Faith and the role it plays in the travelogues is ambiguous and I believe that the literary critical reception of the travelogues has undermined that complexity. Naipaul provides four different perspectives regarding faith, living and modernity. He notes that even in the oil rich secular states of the East, faith and superstition appear to sit in uneasy proximity:

Kamran, in spite of his cynicism, about things generally, had begun to grumble that in the morning ... he hadn't put anything in an alms box ... That was why he had had trouble with the ignition ... the prayers [he] offered were for a safe run back. (Naipaul 1998:234)

In Malaysia, Nasar, the former Muslim youth group leader turned successful businessman, says: 'What they had been looking for religion to do for them in 1979, simple power, simple authority, had done for them later' (Naipaul 1998:391). In Kuala Lumpur, whilst noting the new wealth of the state, Naipaul notes also the fate of the immigrant Chinese, who 'without protection' had been absorbed into Malay society, either as converts to Islam or Christianity: Philip was now 'liberated from those kitchen gods' (ibid:395). For Nadezha, a Westernised woman married to a Malaysian with a rural family, 'There were no cultural interests in the kampong [village]. Life was shallow. There was only religion' (ibid:403). Both husband and wife abandoned religion and divorced. And finally, there is Rashid, a Christian Malay, descended from an Indo-Chinese Taoist-Buddhist traditional healer, whose conversion to Islam had meant purpose and delivery: 'Without Islam ... his life would have been without point' (ibid:415); however, Rashid still appreciates the old customs; he was:

pleased ... that other members of the family would be carrying on [his mother's] worship of her Malay Datuk spirit in her kitchen, and doing the rituals on the family altar. (Naipaul 1998:419)

In all four perspectives, faith sits in uneasy proximity to the possibilities offered by wealth and technological advances, offering both protection and a measure of authenticity to its adherents.

The traces of old religions and observance appear difficult to erase completely even within the context of the wealth of the new state. Naipaul (1998) notes that:

In Jakarta, the new wealth could at times feel oppressive ... new money, new luck made every weekend festive; and on Sunday mornings in the Borobudur Hotel, the rich folk, Chinese and others, from the Bethany Successful Families, one of the few American Evangelical faiths, ... sang hymns, clapped hands ... praying for that luck to last. (p. 419)

And, as if almost by accident, there is in Rashid's account a description of faith that appears to be sincere in its purpose, and which is rendered compassionately by Naipaul (Feder 2001:136). Rashid tells the narrator that his mother's love of community and her Islamic faith were what enabled his father to live in dignity in their home throughout the 23 years of his illness: 'Without her he would have been thrown 
into the madhouse and he wouldn't have lasted two years. As it was, he lived in his two worlds for twenty-three years' (Naipaul 1998:437).

Faith to live by, faith enabling compassion for the suffering of others, and faith ensuring a humble and dignified approach to life and death, is described almost tangentially. Why should this be so? Does Naipaul find in the turmoil of the Middle and Far East, an expression of his own rage against the violence associated with imperialisms of different forms, what Feder (2001) describes as Naipaul's 'truth': 'Islam, almost from the start, had been an imperialism as well as a religion' (ibid:11)?

The oblique references to the possibilities offered by faith when not contorted by power, or reactionary politics, or defiance against an externalised and alien 'West', are enabling and inspire depth of feeling and compassion in the author and indeed in the interviewees. Caught up in the aftermath of dramatic and violent change Naipaul is clearly deeply affected by the context, and the people whom he meets. Evidence of his perceptions can also be seen as equally responsive (and sometimes equally reactionary) to these circumstances. It is possible, as a result of this re-reading of Naipaul, to argue that Islam became the vehicle for the narrator's rage against imperialism and that the religion cannot patently address the many layers of distress experienced by converts desperate to remain connected to ideas of authenticity, place, purpose and value. Religion then becomes an inadequate vehicle for forgetting (Marangoly-George 1996:197) the violence of colonialism and the destruction of holy places associated with conversion and religious conflict.

\section{Reflections}

I began by speculating on the strategies deployed by the narrator in terms of the selection of persons to be interviewed, the erasure of questions posed by the narrator, the ambiguity of the narrator as insider-outsider and postcolonial subject, and the ways in which these positions and strategies construct a perspective on faith in Islamic societies in transition. What emerges in the texts discussed is that far from being oblique, the subject-position taken by the authornarrator is at once intrusive and obscured, authoritative and fragmented. Though not the overt subject of the four travel texts, it is clear that the texts form a dialogue between Islam and the 'West' as rendered by the author-narrator. Far from consenting or even being party to perspectives articulated by the interviewees, the narrator's manipulation of perspective serves a twin purpose: firstly, the creation of an authorial as well as political dialectic in which the contrast between the author-narrator's and interviewee's perspective places a distance between reader, author-narrator and interviewee. Secondly, by allowing for a reading of Naipaul's travelogues to be contrasted with selected contemporary commentary (social, political and historical), I have shown that the discourse crafted by Naipaul is by no means associated with anti-Islamic, or pathological perspectives adopted by the West in relation to the East (a point argued by Said and other postcolonial scholars). Naipaul is not simply a Western mimic of stereotype or prejudice. Ghazoul (1993:158) contends that Said finds himself between 'two civilizational modes ... [partaking] of American and Arab culture' and that this positioning, similar to that which applies to Naipaul, is not necessarily voluntary or complacent. Naipaul argues that the rage experienced in those Islamic societies he visited is directed at the loss of civilisation, and at the erasure of more authentic and local histories, in favour of a seeming vacuity associated with universal religion in which what is local needs to be replaced. This is a convert's choice (and also unforeseen fate) when conversion occurs in the context of wider social and political development in which alternative forms of identity are not recoverable from the past, and not offered by the possibilities suggested in the present.

To some extent it is ironic that Naipaul draws comparisons between colonialism and an Islam in which he sees faith as filled with distortions and simplifications. The question to be asked in the context of the travelogues is whether the conversion is enabling? The answer to this is 'yes and/or no' and it is the tensions between the 'yes and/or no' that Naipaul explores to demonstrate that the distortions of reality, identity, sexuality, and gender offered power to some and alienation to others. What is significant in this re-reading of Naipaul against his critics and in light of the socio-political commentary of scholars outside of postcolonial studies, is the extent to which such a re-reading reveals that the distortion of the narrative reflects as much the author-narrator's rage at the violence and loss, as well as his attempts to refuse to grant it importance.

\section{Acknowledgements Competing interests}

The author declares that he has no financial or personal relationship(s) that may have inappropriately influenced him in writing this article.

\section{References}

Ahmed, A.S., 2004, Postmodernism and Islam: Predicament and promise, rev. edn., Routledge, New York.

Al-Quaderi, G.G. \& Habibullah, M., 2012, 'Travels in absurdity: Islam and V.S. Naipaul', Journal of Postcolonial Cultures and Societies 3(1), 22-37.

Anjum, Z., 2002, 'A convert's complaint: Analyzing Naipaul's views on Islam', viewed 23 July 2010, from http://www.chowk.com/articles/5246

Bhabha, H., 1994, The location of culture, Routledge, London.

Boyd, W., 2010, 'V. S. Naipaul, a misanthrope abroad', The Times Literary Supplement, 06 October, p. 1.

Coovadia, I., 2009, Authority and authorship in V.S. Naipaul, Palgrave, London. http:// dx.doi.org/10.1057/9780230622463

Donadio, R., 2005, 'The irascible prophet: V.S. Naipaul at home', The New York Times, viewed 30 August 2010, from http://www.nytimes.com/2005/08/07/books/ viewed 30 August 2010, from $h t t p: / / w w w . n$
review/07DONADIO.html?pagewanted $=a l l \&_{-} r=0$

Feder, L., 2001, Naipaul's truth: The making of a writer, Rowman and Littlefield Publishers, Maryland.

Ghazoul, F.J., 1993, 'The resonance of the Arab-Islamic heritage in the work of Edward Said', in M. Sprinker (ed.), Edward Said: A critical reader, pp. 157-172, Blackwell Press, Oxford.

Gibbons, F., 2001, 'V.S. Naipaul launches attack on Islam', The Guardian, 04 October 2001, p. 1.

GoGwilt, C., 1995, The invention of the West: Joseph Conrad and the double mapping of Europe and Empire, Stanford University Press, Redwood City. 
Hardt, M, \& Negri, A., 2001, Empire, Harvard University Press, Cambridge.

Marangoly-George, R., 1996, The politics of home: Postcolonial relocations and twentieth-century fiction, Cambridge University Press, Cambridge.

Mazrui, A.A., 2006, Islam: Between globalisation and counter-terrorism, James Currey Press, Oxford.

Mamdani, M., 1996, Citizen and subject, Princeton University Press, Princeton.

Naipaul, V.S., 1964, An area of darkness, Penguin Books, London.

Naipaul, V.S., 1979, A Bend in the River, Penguin Books, Harmondsworth.

Naipaul, V.S., 1981, Among the believers, Penguin Books, London.

Naipaul, V.S., 1990, India: A million mutinies now, Minerva, London.

Naipaul, V.S., 1998, Beyond belief, Little, Brown and Company, London.

Nixon, R., 1992, London calling: V.S. Naipaul postcolonial mandarin, Oxford University
Rush, N., 2010, 'Naipaul's mysterious Africa', The New York Review of Books, 11 November 2010, p. 4.

Said, E., 1991, Orientalism, Penguin Books, London.

Said, E., 1994, Culture and imperialism, Vintage, New York.

Sprinker, M., (ed.), 1993, Edward Said: A critical reader, Blackwell Press, Oxford.

Spivak, G., c. 1988. 'Can the subaltern speak?', in C. Nelson \& L. Grossberg (eds.), Marxism and the interpretation of culture, pp. 271-313, University of Illinois Press, Urbana.

Theroux, P., 1998, Sir Vidia's shadow: A friendship across five continents, Mariner Books, New York.

Waines, D., 2003, An introduction to Islam, Cambridge, University Press, Cambridge.

Zakariyya, F., 2005, Myth and reality in the contemporary Islamist movement, transl. I.M. AbuRabi, Pluto Press, London. 